\title{
Hydrogen Peroxide-Induced Oxidative Damage in Human Chondrocytes: The Prophylactic Effects of Hypericum Perforatum Linn Extract on Deoxyribonucleic acid Damage, Apoptosis and Matrix Remodeling by a Disintegrin-Like and Metalloproteinase With Thrombospondin Motifs Proteinases
}

\author{
Sümeyya AKYOL, ${ }^{1}$ Yunus YÜKSELTEN, ${ }^{2}$ Özlem ÇAKMAK, ${ }^{3}$ Veli UĞURCU, ${ }^{4}$ Aynur ALTUNTAŞ, ${ }^{5}$ \\ Mukaddes GÜRLER, ${ }^{6}$ Ömer AKYOL, ${ }^{6}$ Kadir DEMİCAN ${ }^{1}$ \\ ${ }^{1}$ Department of Medical Biology, Medical Faculty of Turgut Özal University, Ankara, Turkey \\ ${ }^{2}$ Department of Medical Biology, Medical Faculty of Ankara University, Ankara, Turkey \\ ${ }^{3}$ Department of Biology Education, Gazi University, Faculty of Education, Ankara, Turkey \\ ${ }^{4}$ Department of Medical Biochemistry, Medical Faculty of Dumlupinar University, Kütahya, Turkey \\ ${ }^{5}$ Department of Chemistry, Ankara Regional Office of Council of Forensic Medicine, Ankara, Turkey \\ ${ }^{6}$ Department of Medical Biochemistry, Medical Faculty of Hacettepe University, Ankara, Turkey
}

\begin{abstract}
Objectives: This in vitro study aimed to examine the protective roles of Hypericum perforatum Linn (HPL) extract on cell viability, DNA damage, apoptosis and a disintegrin-like and metalloproteinase with thrombospondin motifs (ADAMTS) proteins in chondrocytes induced by hydrogen peroxide $\left(\mathrm{H}_{2} \mathrm{O}_{2}\right)$, as a model of chondrocytes subjected to reactive oxygen species (ROS) attack in rheumatoid arthritis and osteoarthritis.

Materials and methods: Human chondrosarcoma cell line (OUMS-27) was used. Cells were incubated with different concentrations of methanolic extract $(100,400$, and $750 \mu \mathrm{g} / \mathrm{ml})$ of HPL for 36 hours, and then treated with $0.7 \mathrm{mM} \mathrm{H}_{2} \mathrm{O}_{2}$ for two hours. Trypan blue was used for evaluation of cell viability, while DNA damage was evaluated by alkaline Comet assay. Caspase-1, ADAMTS5, ADAMTS9, and glyceraldehyde-3-phosphate dehydrogenase (GAPDH) proteins were analyzed by Western blot.

Results: In vitro $\mathrm{H}_{2} \mathrm{O}_{2}$ treatment decreased OUMS-27 cell viability. Cells pretreated with HPL at concentration of $400 \mu \mathrm{g} / \mathrm{mL}$ were best protected from $\mathrm{H}_{2} \mathrm{O}_{2}$ toxicity. Compared to $100 \mu \mathrm{g} / \mathrm{ml}$ concentration, pretreatment of cells with 750 or $400 \mu \mathrm{g} / \mathrm{ml}$ of HPL generated more protection against $\mathrm{H}_{2} \mathrm{O}_{2}$-induced DNA damage. Hydrogen peroxide application to the cells led to a slight increase in Caspase-1 expression, which shows no apoptosis. The most prominent increase in Caspase- 1 level was shown in cells treated with $400 \mu \mathrm{g} / \mathrm{ml}$ of HPL extract. There was an increase in ADAMTS9 and a decrease in ADAMTS5 levels upon $\mathrm{H}_{2} \mathrm{O}_{2}$ administration. Pretreatment with HPL led to more decrease in ADAMTS5 level, indicating the protection of extracellular matrix attacked by these proteinases in cartilage tissue.

Conclusion: It can be concluded that HPL has a potential to reverse the negative effects and processes induced by $\mathrm{H}_{2} \mathrm{O}_{2}$ in OUMS-27 cells and it can protect the surrounding cartilage area of chondrocytes from oxidative damage, which is suggested to be one of the main molecular factors accused for progression of rheumatoid arthritis and osteoarthritis.

Key words: A disintegrin-like and metalloproteinase with thrombospondin motifs; apoptosis; hydrogen peroxide; Hypericum perforatum; OUMS-27.
\end{abstract}

Oxidative stress (OS) has been implicated in initiating, accompanying or causing many diseases. Progression of rheumatoid arthritis (RA) and osteoarthritis (OA) has been associated with $\mathrm{OS}$ and inflammation. Identifying the molecular mechanisms of OS and reactive oxygen species (ROS) in RA and OA patients is important for understanding the pathophysiology of these diseases. Hydrogen peroxide $\left(\mathrm{H}_{2} \mathrm{O}_{2}\right)$ inhibits synthesis of proteoglycan structure in

Received: July 17, 2014 Accepted: August 08, 2014

Correspondence: Sümeyya Akyol, M.D. Turgut Özal Üniversitesi Tıp Fakültesi Tıbbi Biyoloji Anabilim Dalı, 06560 Yenimahalle, Ankara, Turkey.

Tel: +90 312 - 3977400 e-mail: sumeyyaak@hotmail.com

○2014 Turkish League Against Rheumatism. All rights reserved. 
cartilage via adenosine triphosphate synthesis and inhibition of glyceraldehyde-3-phosphate dehydrogenase (GAPDH), a glycolytic enzyme in chondrocytes. ${ }^{1}$

The chemicals which prevent ROS generation have been evaluated to reduce the ROS-induced tissue damage. Recent literature suggests that numerous plant products such as terpenes, flavonoids, and polyphenols present antioxidant effects. One of the most studied medicinal plants, Hypericum perforatum Linn (HPL), has been used as a remedy for several diseases and pathologies with few side effects, ${ }^{2}$ and the extract of this plant showed excellent antioxidant activity in vitro. ${ }^{3,4} \mathrm{HPL}$ has also been observed to possess anti-inflammatory activities. ${ }^{5,6}$ Most of the studies on this plant are related with its antidepressant activity. The actions of flavonoids have not been totally evaluated for other possible therapeutic effects. ${ }^{7}$ The extract of HPL may have therapeutic value for the management of RA or OS due to its antioxidant activity.

Literature data is limited about the effects of $\mathrm{H}_{2} \mathrm{O}_{2}$, one of the main ROS, on chondrocytes in terms of deoxyribonucleic acid (DNA) damage, apoptosis, and a disintegrin-like and metalloproteinase with thrombospondin motifs (ADAMTS) proteins/enzymes. This study primarily aimed to evaluate the effects of $\mathrm{H}_{2} \mathrm{O}_{2}$ on DNA damage, apoptosis, and ADAMTS translation in chondrosarcoma cells. Secondarily, we aimed to study whether $\mathrm{H}_{2} \mathrm{O}_{2}$-induced oxidative injury in an in vitro experimental setup could be prevented by HPL extract.

\section{MATERIALS AND METHODS}

Extract preparation: This study was performed between June 15 and July 5, 2014 in Laboratory of Medical Biology, Turgut Özal University Medical Faculty, Ankara. Dried HPL flower was extracted by using absolute methanol. Then, the methanol extracts were filtered, evaporated to a thick residue at $40{ }^{\circ} \mathrm{C}$, and finally stored at $4{ }^{\circ} \mathrm{C}$ until use.

Cell culture and treatment: Dulbecco's modified Eagle's medium (DMEM) was used for the culture of human chondrosarcoma cell line
(OUMS-27). Dulbecco's modified Eagle's medium was supplemented with $10 \%$ fetal bovine serum at $37{ }^{\circ} \mathrm{C}$ in $5 \% \mathrm{CO}_{2}$. The OUMS-27 cell line without extract or $\mathrm{H}_{2} \mathrm{O}_{2}$ was used as negative control. Hydrogen peroxide treated group without extract administration was used as positive control. Cells were incubated with different concentrations of methanolic extract $(100,400$, and $750 \mu \mathrm{g} / \mathrm{ml})$ of HPL for 36 hours, and then treated with $0.7 \mathrm{mM}$ $\mathrm{H}_{2} \mathrm{O}_{2}$ for two hours.

Cell viability assay: Trypan blue $[0.4 \%$ in phosphate buffered saline (PBS) scorecard] staining was used for the assessment of cell viability. The cells were trypsinized and detached from the culture dish; later, harvested and mixed with an equal volume (1:1) of trypan blue. The resultant product was counted on a hemocytometer. Trypan blue is only permeable to the cells with damaged membrane. Six random fields were chosen for the analysis. A survival ratio of $100 \%$ was assumed for the undamaged cells in the control group, and the other groups were compared with the control for the calculation of the survival rates.

Alkalin Comet Assay for the determination of DNA Damage: Single cell gel electrophoresis (comet assay) enables the measurement of DNA damage and the evaluation of mechanisms of cytotoxic and genotoxic effects of substances on organisms. The method described by Singh et al. $^{8}$ was used with minor modifications. Ten microliters (around 20,000 cells) of OUMS-27 cell suspension treated with different concentrations of HPL extract was mixed with low melting point agarose (LMA from Sigma-Aldrich Chemie $\mathrm{GmbH}$., Schnelldorf, Germany, $80 \mu \mathrm{l}$ of $0.7 \%$ in PBS) at $37{ }^{\circ} \mathrm{C}$. Then, the mixture $(80 \mu \mathrm{L})$ was layered onto the slides previously coated with normal melting point agarose (NMA, $1.0 \%$ at $60{ }^{\circ} \mathrm{C}$ ). For the solidification of the agarose, it was covered with a coverslip at $4{ }^{\circ} \mathrm{C}$ for five minutes. After the removal of the cover, the slides were treated with fresh $4{ }^{\circ} \mathrm{C}$ cold lyses solution $(2.5 \mathrm{M}$ $\mathrm{NaCl}, 10 \mathrm{mM}$ Tris- $\mathrm{HCl}$ and $100 \mathrm{mM} \mathrm{Na} 2$ EDTA at $\mathrm{pH}$ 10-10.5). Dimethyl sulfoxide (10\%) and Triton X-100 (1\%) were added to the solution just before its use. Slides were put into fresh alkaline electrophoresis buffer $(0.3 \mathrm{mM} \mathrm{NaOH}$ and $1 \mathrm{mM}$ $\mathrm{Na}_{2}$ EDTA at $\mathrm{pH}>13$ ) and electrophoresed at $25 \mathrm{~V} / 300 \mathrm{~mA}$ for 25 minutes. All the steps were conducted under red light or without direct 
Table 1. Primary and secondary antibodies used for Western blot techniques. 105 is inactive and 75 is active bands in ADAMTS5

\begin{tabular}{lccccc}
\hline $\begin{array}{l}\text { Primary } \\
\text { antibodies }\end{array}$ & $\begin{array}{c}\text { Primary antibodies } \\
\text { concentration }\end{array}$ & $\begin{array}{c}\text { Secondary } \\
\text { antibodies }\end{array}$ & $\begin{array}{c}\text { Secondary antibodies } \\
\text { concentration }\end{array}$ & Reaction & $\mathrm{kDa}$ \\
\hline Caspase-1 & $1 / 1000$ & Rabbit & $1 / 4000$ & Mouse, rat, human & 50 \\
ADAMTS5 & $1 / 1000$ & Hare & $1 / 4000$ & Mouse, rat, human & $75 / 105$ \\
ADAMTS9 & $1 / 1000$ & Goat & $1 / 4000$ & Mouse, rat, human & 180 \\
GAPDH & $1 / 10000-1 / 50000$ & Rabbit & $1 / 4000$ & Human & 36 \\
\hline $\begin{array}{l}\text { ADAMTS: A disintegrin-like and metalloproteinase with thrombospondin } \\
\text { dehydrogenase. }\end{array}$ & & & & \\
\hline
\end{tabular}

light to prevent additional DNA damage. After the electrophoresis, the slides were stained with ethidium bromide $(70 \mu \mathrm{L} /$ slide $)$ and analyzed using a fluorescence microscope (Olympus Optical Co. Ltd., Hatagaya, Shibuya-ku, Tokyo, Japan). The images from 100 randomly selected nuclei were analyzed for each sample as described elsewhere. ${ }^{9}$ The intensity of the fluorescence in the comet tail was scored as $0,1,2,3$, or 4 (undamaged as 0 and maximal damage as 4); therefore, the total score of each slide varied between 0 and 400 arbitrary units (AU).

Protein extraction, Western blot analysis, and antibodies: Anti-caspase-1, anti-ADAMTS5, anti-ADAMTS9, and anti-GAPDH primary antibodies (Table 1) were purchased from Santa Cruz (Santa Cruz Biotechnology, Inc., CA, USA) and used in 1:100 dilution. Before the study, cross-reactivity was confirmed as stated in the manufacturer's data sheet. Then, the cells were rinsed with PBS once and scraped from the plates. Cells were solubilized in $200 \mu \mathrm{L}$ of CelLytic TMM (Sigma-Aldrich Chemie GmbH., Schnelldorf, Germany) with a mixture of protease inhibitor. After incubating in a rotator at $4{ }^{\circ} \mathrm{C}$ for 15 minutes, the cells were centrifuged, and then the supernatant was collected. The protein concentration of the samples was analyzed by using a proteinassay kit (Thermo Scientific Bradford Assay Kit, Rockford, IL, USA), and standard bovine serum albumin. Protein samples were boiled at $95{ }^{\circ} \mathrm{C}$ within Laemli Sample buffer and $\beta$-mercaptoetanol for eight minutes. Western blot was performed with the $10 \mu \mathrm{g}$ of the total protein. Briefly, $10 \mu \mathrm{L}$ of each sample including protein marker (Bio-Rad Precision Plus Protein Western C Standard) were loaded to Western blot gel (Bio-Rad Mini-PROTEAN
TGX Stain-Free Gels, 4-15\%, 15-well comb, $15 \mu \mathrm{L})$ within Bio-Rad 1x Tris/Glycerine/ SDS running buffer and run at $250 \mathrm{~V}$ for 20 minutes. After electrophoresis, proteins were transferred to the polyvinylidene difluoride (PVDF) membrane (Bio-Rad Trans-Blot Turbo Transfer Pack, $0.22 \mu \mathrm{M}$ PVDF) by using transfer system (Bio-Rad Trans-Blot Turbo Transfer System, Singapore). Membranes were blocked for one hour in 2.5\% nonfat dried skim milk in tris-buffered saline (TBS) with $0.05 \%$ of Tween 20 (TBS-T). The membrane was incubated overnight (approximately 16 hours) with the primary anti-Caspase-1, anti-ADAMTS4, anti-ADAMTS9, and anti-GAPDH antibodies (Table 1) diluted in blocking buffer. After

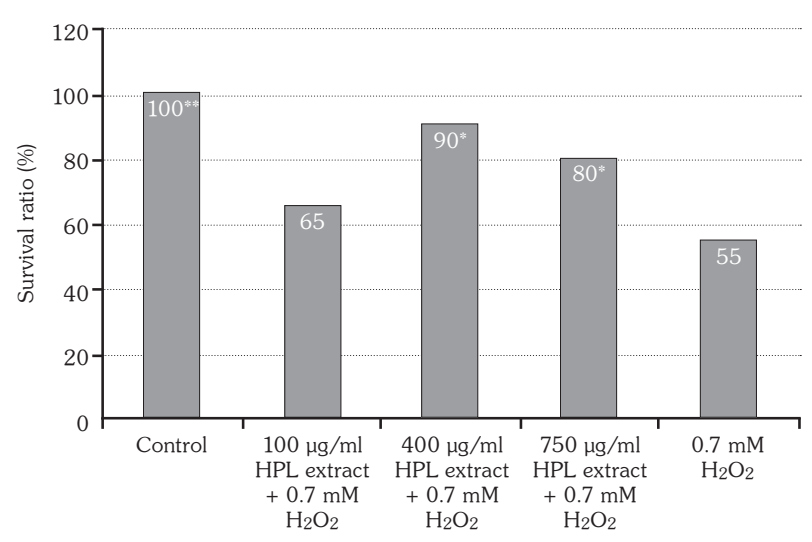

Figure 1. Cell viability results assayed by trypan blue staining. Effects of methanolic extracts of Hypericum perforatum Linn on OUMS-27 cells treated by $\mathrm{H}_{2} \mathrm{O}_{2}$. Cells were pretreated with different concentrations of methanolic extract of HPL for 36 hours, and then treated with $0.7 \mathrm{mM} \mathrm{H}_{2} \mathrm{O}_{2}$ for two hours. Positive control cells were only treated with $\mathrm{H}_{2} \mathrm{O}_{2}$ but no extract, and there was no treatment in control cells. HPL: Hypericum perforatum Linn; $\mathrm{H}_{2} \mathrm{O}_{2}$ : Hydrogen peroxide; *Values are significantly different compared with $\mathrm{H}_{2} \mathrm{O}_{2}$ treated cells $(\mathrm{p} \leq 0.05) ;{ }^{* *}$ Values are significantly different compared with $\mathrm{H}_{2} \mathrm{O}_{2}$ treated cells $(\mathrm{p} \leq 0.01)$. 


\begin{tabular}{|c|c|c|}
\hline Treatment & Cell survival rate $\%$ & DNA damage (0-400 AU) \\
\hline Control & $100^{* * *}$ & 102 \\
\hline $100 \mu \mathrm{g} / \mathrm{ml} \mathrm{HPL} \mathrm{extract}+0.7 \mathrm{mM} \mathrm{H}_{2} \mathrm{O}_{2}$ & 65 & 353 \\
\hline $400 \mu \mathrm{g} / \mathrm{ml} \mathrm{HPL}$ extract $+0.7 \mathrm{mM} \mathrm{H}_{2} \mathrm{O}_{2}$ & $90^{*}$ & 281 \\
\hline $750 \mu \mathrm{g} / \mathrm{ml} \mathrm{HPL}$ extract $+0.7 \mathrm{mM} \mathrm{H}_{2} \mathrm{O}_{2}$ & $80^{*}$ & 304 \\
\hline $0.7 \mathrm{mM} \mathrm{H}_{2} \mathrm{O}_{2}$ & 55 & 364 \\
\hline
\end{tabular}

stringent washing with TBS-T three times for eight minutes each at room temperature, the membranes were incubated one hour with the appropriate secondary antibodies (Table 1). Following three washes with TBS-T, immunoreactive bands were visualized with the enhanced chemiluminescence system (Bio-Rad Immun-Star Western C kit) for 90 seconds. Signals were detected with an imaging system (Bio-Rad ChemiDoc MP Imaging System, Singapore), and the density was analyzed using Image J software (W. Rasband, Research Services Branch, NIMH, NIH, Bethesda, MD) and normalized with the signal of GAPDH for equal protein loading control of each sample in each experiment. This quantification was performed with the linear range of the standard curve defined by the standard sample, GAPDH, for all densitometry analysis.

\section{Statistical analyses}

Statistical Package for Social Science (SPSS) version 16.0 (SPSS Inc., Chicago, IL, USA) was used for statistical tests, and Student's t-test, which measures the significance of differences between the means, was applied. A $p$ value of $<0.05$ was accepted as significant.

\section{RESULTS}

In the primary part of the study, $\mathrm{H}_{2} \mathrm{O}_{2}$ decreased cell viability as shown in Figure 1 and Table 2. Figure 1 also presents the protective effect of $\mathrm{HPL}$ extract against $\mathrm{H}_{2} \mathrm{O}_{2}$-induced cytotoxicity in the OUMS-27 cells. The cell viability decreased significantly compared to the control cells when they were treated with $\mathrm{H}_{2} \mathrm{O}_{2}(0.7 \mathrm{mM})$ for two hours. On the other hand, the viability of OUMS-27 cells increased in the cells pretreated with HPL extract for
36 hours prior to $\mathrm{H}_{2} \mathrm{O}_{2}$ exposure, compared to cells without pretreatment with the extract. So, the most protective effect was observed at the $400 \mu \mathrm{g} / \mathrm{mL}$ concentration of the extract.

To confirm the protective effect of HPL on the apoptosis caused by $\mathrm{H}_{2} \mathrm{O}_{2}$, DNA damage was analyzed by using the comet assay (Figure 2), which is a simple yet sensitive technique for the detection of DNA damage for
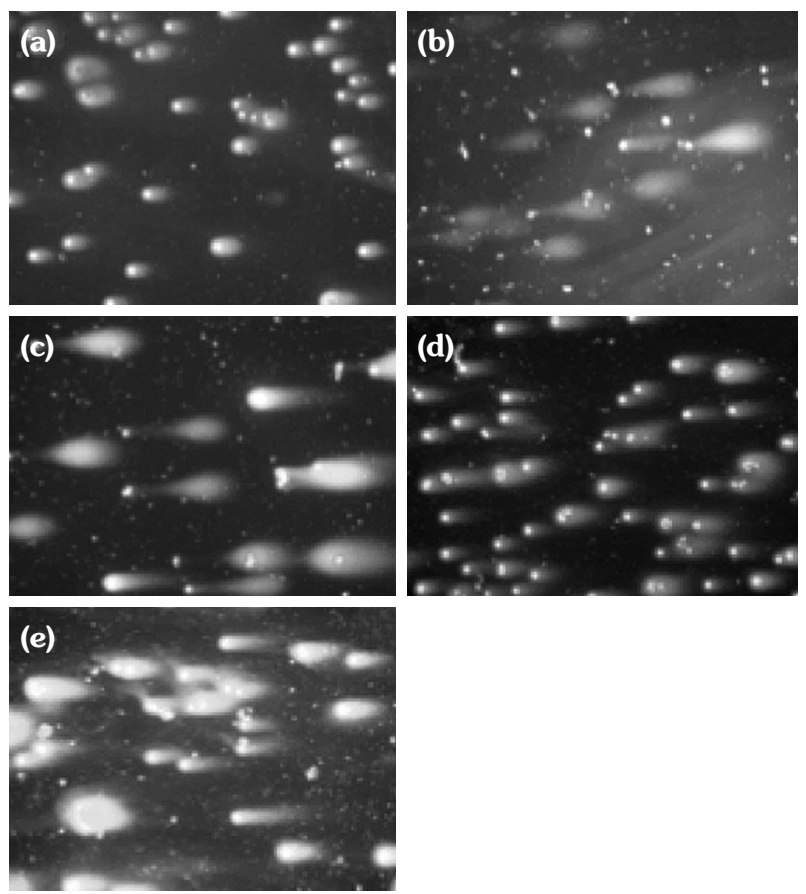

Figure 2. Deoxyribonucleic acid damage visual classification, according to the relative proportion of deoxyribonucleic acid in the tail (cells between 0 and 4), provided from single-cell gel electrophoresis. "0" is undamaged cell, and " 4 " is the most heavily damaged cell. (a) Control cells, (b) positive control cells; treated only with $0.7 \mathrm{mM} \mathrm{H}_{2} \mathrm{O}_{2}$, (c) $100 \mu \mathrm{g} / \mathrm{ml} \mathrm{HPL} \mathrm{extract} \mathrm{+}$ $0.7 \mathrm{mM} \mathrm{H}_{2} \mathrm{O}_{2}$, (d) $400 \mu \mathrm{g} / \mathrm{ml} \mathrm{HPL}$ extract $+0.7 \mathrm{mM}$ $\mathrm{H}_{2} \mathrm{O}_{2}$, (e) $750 \mu \mathrm{g} / \mathrm{ml} \mathrm{HPL}$ extract $+0.7 \mathrm{mM} \mathrm{H} \mathrm{H}_{2}$. HPL: Hypericum perforatum Linn; $\mathrm{H}_{2} \mathrm{O}_{2}$ : Hydrogen peroxide. 
eukaryotic cells. Comet refers to the pattern of DNA migration through the electrophoresis gel because of the analogy with a comet. Figure 2 shows no tail on "A" (control cells) and almost no tail on " $D$ " (cells preconditioned by $400 \mu \mathrm{g} / \mathrm{ml} \mathrm{HPL}$ extract). Deoxyribonucleic acid damage scores are presented in Figure 3 by using arbitrary units. According to this figure, the use of $0.7 \mathrm{mM}$ of $\mathrm{H}_{2} \mathrm{O}_{2}$ significantly induced the DNA damage compared to the other concentrations of HPL and control cells. Pretreatment of cells with $100 \mu \mathrm{g} / \mathrm{ml} \mathrm{HPL}$ hardly protects cells from $\mathrm{H}_{2} \mathrm{O}_{2}$-induced DNA damage compared to $\mathrm{H}_{2} \mathrm{O}_{2}$ alone (arbitrary unit 353 vs. 364). However, pretreatment of cells with $750 \mu \mathrm{g} / \mathrm{ml} \mathrm{HPL}$ and $400 \mu \mathrm{g} / \mathrm{ml}$ HPL extracts provided cells a strong protection

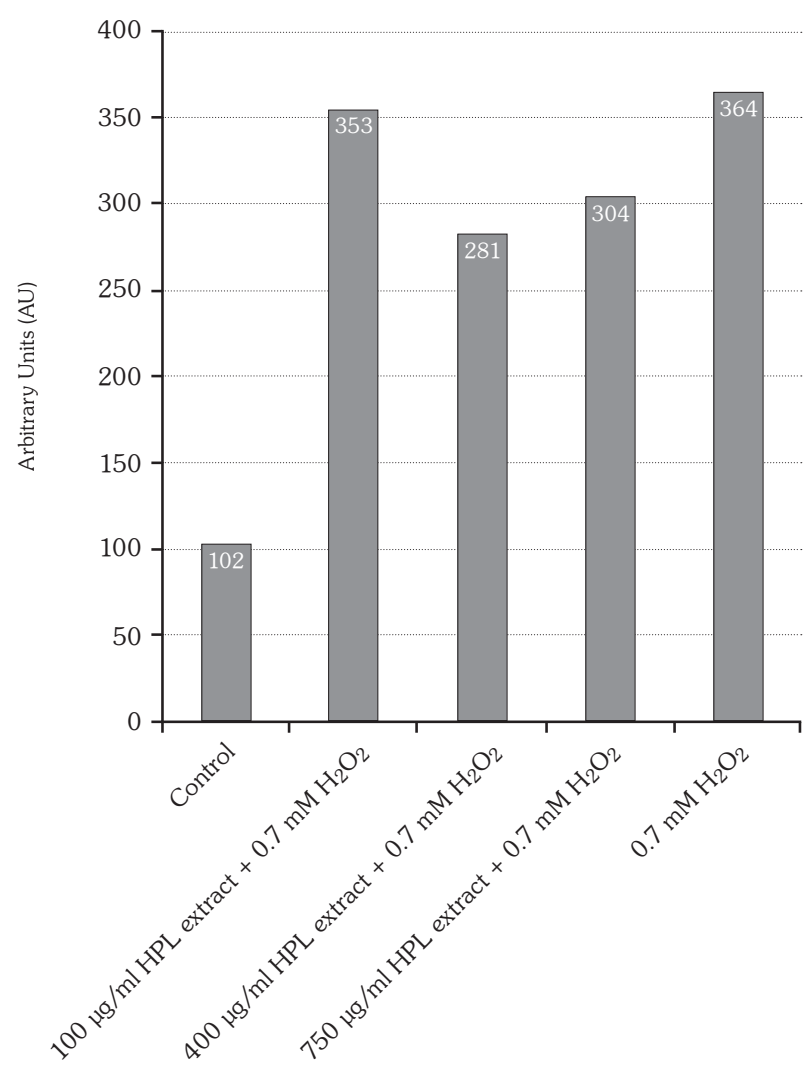

Figure 3. Deoxyribonucleic acid damage graphical classification, according to the relative proportion of DNA in the tail (cells between 0 and 4), provided from single-cell gel electrophoresis. Images were classified according to nucleus scale and tail length given a value between 0 and 4 (undamaged class "0", maximally damaged class "4"). Total DNA damage score varied between 0 and 400 arbitrary units (AU). HPL: Hypericum perforatum Linn; $\mathrm{H}_{2} \mathrm{O}_{2}$ : Hydrogen peroxide; DNA: Deoxyribonucleic acid. from DNA damage (304 and 281 arbitrary units, respectively).

Western blot analyses showed that all studied proteins are expressed and translated in OUMS-27 cell line (Figure 4). Bands for Caspase-1, ADAMTS5, ADAMTS9, and GAPDH were detected in places where they were anticipated to be found (Figure 4). Total $0.7 \mathrm{mM} \mathrm{H}_{2} \mathrm{O}_{2}$ led to a slight increase in Caspase-1 amount, which shows no apoptosis at all (Figure 5). The most prominent increase in Caspase-1 level was shown in cells treated with $400 \mu \mathrm{g} / \mathrm{ml}$ of HPL (Figure 5). Caspase-1/GAPDH ratio in this group was 3.41 compared to the control value of 1 . It was followed by the cells pretreated with $750 \mu \mathrm{g} / \mathrm{ml}$ of HPL (2.20) and $100 \mu \mathrm{g} / \mathrm{ml}$ of HPL (1.69). Therefore, cells pretreated with $400 \mu \mathrm{g} / \mathrm{ml}$ of HPL are expected to have more apoptosis compared to all other groups. The ADAMTS5 levels decreased significantly in the cells treated with $0.7 \mathrm{mM} \mathrm{H}_{2} \mathrm{O}_{2}$ (ADAMTS5/GAPDH ratio is 0.357) compared to the control cells (ADAMTS5/ GAPDH ratio is 1) (Figure 6). Pretreatment of cells with 400 and $100 \mu \mathrm{g} / \mathrm{ml}$ of HPL decreased ADAMTS5 levels more significantly compared to the $\mathrm{H}_{2} \mathrm{O}_{2}$ group (ADAMTS5/GAPDH ratio was 0.226 and 0.122 vs. 0.357 , respectively). On the contrary, ADAMTS9 levels increased in $0.7 \mathrm{mM} \mathrm{H}_{2} \mathrm{O}_{2}$ group (the ratio for ADAMTS9/ GAPDH was 1.261) compared to the control cells (ratio: 1) (Figure 7). Cells pretreated with 750 and $400 \mu \mathrm{g} / \mathrm{ml} \mathrm{HPL}$ significantly decreased ADAMTS9 levels compared to all other groups (ratios were 0.880 and 0.928 , respectively) (Figure 7).

\section{DISCUSSION}

The primary aim of the present study was to test the hypothesis that $\mathrm{H}_{2} \mathrm{O}_{2}$ might change the level of Caspase-1 enzyme in chondrosarcoma cells leading to the changes in apoptosis and structural pathways of cells. Results of our study demonstrated that, contrary to previous studies, $\mathrm{H}_{2} \mathrm{O}_{2}$ may not induce chondrocyte apoptosis through caspase activation. ${ }^{10,11}$ The secondary aim of the study was to evaluate the putative protective effect(s) of HPL extract against $\mathrm{H}_{2} \mathrm{O}_{2}$ induced alterations in apoptosis rate as well as the differences in aggrecan degradation in 
WB: Caspase-1

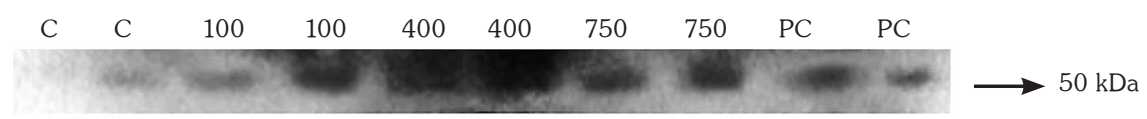

WB: ADAMTS5

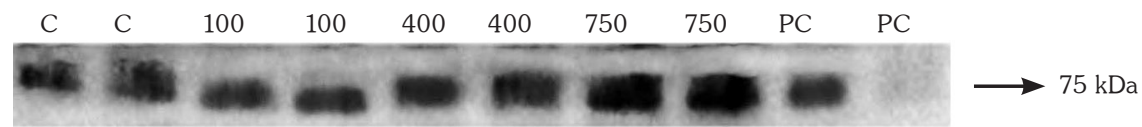

WB: ADAMTS9

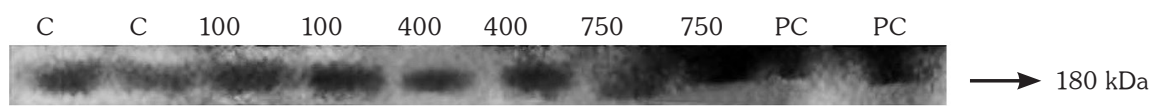

\section{WB: GAPDH}

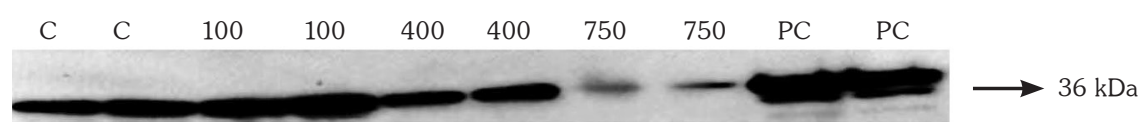

Figure 4. Gel electrophoresis imaging of Western blot technique of Caspase-1 $(50 \mathrm{kDa})$, ADAMTS5 $(75 \mathrm{kDa})$, ADAMTS9 $(180 \mathrm{kDa})$, and glyceraldehyde-3phosphate dehydrogenase $(36 \mathrm{kDa})$ bands. ADAMTS: A disintegrin-like and metalloproteinase with thrombospondin motifs.

OUMS-27 cells using a viability test, comet assay, Caspase-1, and ADAMTS enzymes. Chondrocytes were pretreated with HPL extract and incubated with $\mathrm{H}_{2} \mathrm{O}_{2}$. The apoptosis was evaluated after two hours of exposure to $\mathrm{H}_{2} \mathrm{O}_{2}$.

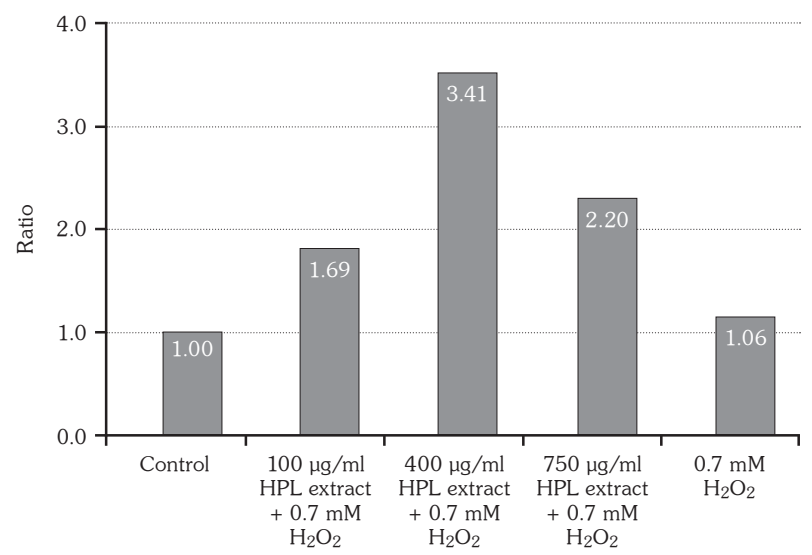

Figure 5. The bar graphics of calculated band densities of both Caspase-1 and glyceraldehyde-3-phosphate dehydrogenase bands. The obtained values were standardized by dividing Caspase-1 to glyceraldehyde-3phosphate dehydrogenase. Control value was divided to control value and therefore was adjusted to " 1 ". The other groups were divided to control values to get the present values. HPL: Hypericum perforatum Linn; $\mathrm{H}_{2} \mathrm{O}_{2}$ : Hydrogen peroxide.
Pretreatment of cells with HPL did not decrease the apoptosis rate, on the contrary, it led to an increase in the number of apoptotic cells. It is known that OS is related with the progress of $\mathrm{OA}$ and RA; therefore, the results of this study

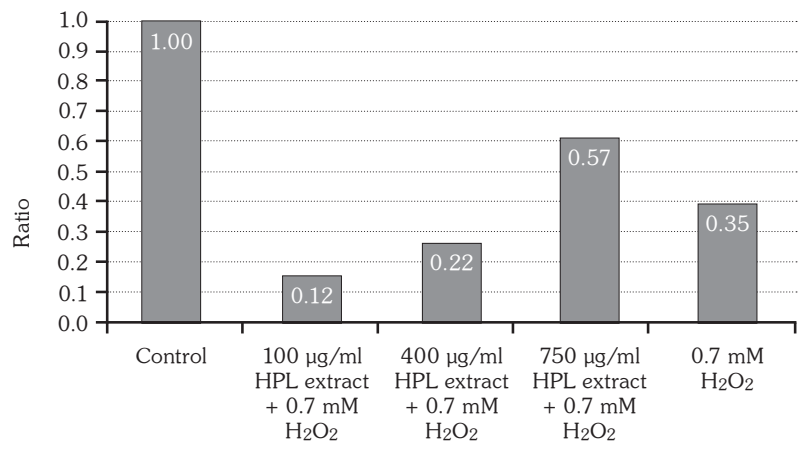

Figure 6. The bar graphics of calculated band densities of both a disintegrin-like and metalloproteinase with thrombospondin motifs 5 and glyceraldehyde-3phosphate dehydrogenase bands. The obtained values were standardized by dividing a disintegrin-like and metalloproteinase with thrombospondin motifs 5 to glyceraldehyde-3-phosphate dehydrogenase. Control value was divided to control value and therefore was adjusted to "1". The other groups were divided to control values to get the present values. HPL: Hypericum perforatum Linn; $\mathrm{H}_{2} \mathrm{O}_{2}$ : Hydrogen peroxide. 


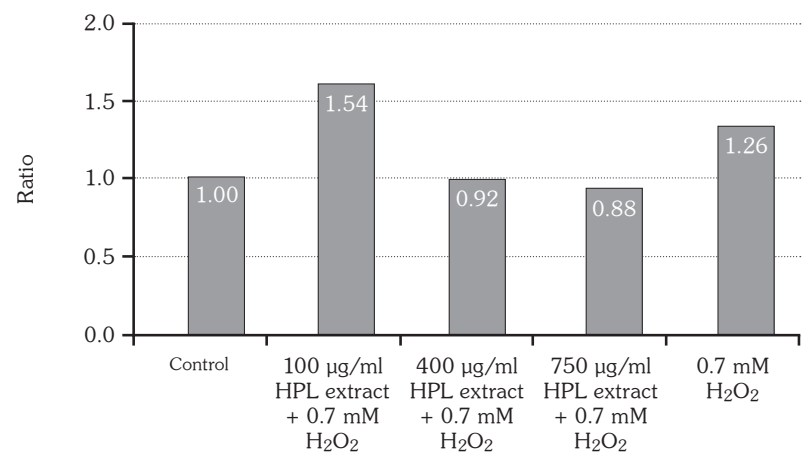

Figure 7. The bar graphics of calculated band densities of both a disintegrin-like and metalloproteinase with thrombospondin motifs 9 and glyceraldehyde-3phosphate dehydrogenase bands. The obtained values were standardized by dividing a disintegrin-like and metalloproteinase with thrombospondin motifs 9 to glyceraldehyde-3-phosphate dehydrogenase. Control value was divided to control value and therefore was adjusted to "1". The other groups were divided to control values to get the present values. HPL: Hypericum perforatum Linn; $\mathrm{H}_{2} \mathrm{O}_{2}$ : Hydrogen peroxide.

suggest that dietary plant food including phenolic antioxidant substances may be useful for the prevention of these clinical conditions.

ADAMTSs family consists of new proteinases. This proteinase enzyme group is primarily located in the extracellular matrix (ECM). It is a member of matrix metalloproteinase (MMP) family in the ECM which breaks substrates such as aggrecan, versican, brevican, nidogen, and procollagen. It has 19 members, and different functions have been identified for each member. They are involved in many physiological processes including ECM turnover, coagulation, angiogenesis and ovulation, as well as pathological processes such as arthritis, atherosclerosis, and cancer.

Since $\mathrm{H}_{2} \mathrm{O}_{2}$ can easily cross the membrane thereby reaching into the cell, it has been suggested as an important signaling substance (Figure 8). ${ }^{12}$ $\mathrm{H}_{2} \mathrm{O}_{2}$ can change cellular functions via modulation of intracellular signals and cause cellular damage and oxidation of protein thiol groups. ${ }^{13}$ Studies in the literature emphasized the harmful effect of $\mathrm{H}_{2} \mathrm{O}_{2}$ on articular cartilage. ${ }^{14-16}$ Schalkwijk et al. $^{17}$ described an experimental model with $\mathrm{H}_{2} \mathrm{O}_{2}$ in order to clarify its destructive effect, in vivo. Inhibition of proteoglycan production and chondrocyte death by $\mathrm{H}_{2} \mathrm{O}_{2}$ were demonstrated in that model. In the recent studies, $\mathrm{H}_{2} \mathrm{O}_{2}$ has been reported to inhibit caspase activity directly in Jurkat cells. ${ }^{18}$ This was supported by the data in the present study. Researchers also report that $\mathrm{H}_{2} \mathrm{O}_{2}$ results in the apoptosis, inhibition of proteoglycan production, and increased extracellular signalregulated kinases activity concluding the important role of $\mathrm{H}_{2} \mathrm{O}_{2}$ in modulation of the metabolism of chondrocytes. ${ }^{11}$

Chondrocytes are placed in a nonvascular matrix and exposed to partial presence of oxygen, and display mainly anaerobic metabolism. Therefore, they are vulnerable to the effect of ROS. It was demonstrated that $\mathrm{H}_{2} \mathrm{O}_{2}$ induces apoptosis in the chondrocytes. ${ }^{11}$ Morphological changes, some biochemical and molecular markers like terminal deoxynucleotidyl transferase and annexin determine whether a cell is undergoing apoptosis or necrosis. In the early stages of apoptosis, expression of some proteins like caspase proteases increases since they are essential for apoptotic signaling pathways. ${ }^{19}$ Chondrocytes produce $\mathrm{ROS}$, including $\mathrm{H}_{2} \mathrm{O}_{2}$, in response to a number of stimuli. We mimicked $\mathrm{H}_{2} \mathrm{O}_{2}$ by giving it externally to the cell culture. Nicotinamide adenine dinucleotide phosphate-oxidase is a potential $\mathrm{H}_{2} \mathrm{O}_{2}$ source in the cartilage. ${ }^{20,21}$ $\mathrm{H}_{2} \mathrm{O}_{2}$ at $\mathrm{mM}$ concentrations has been shown to induce apoptosis in cartilage. ${ }^{22}$ Treatment of chondrocytes with $50-100 \mu \mathrm{M} \mathrm{H}_{2} \mathrm{O}_{2}$ for one day was reported to induce the transcription factor activator protein 1 and to up-regulate matrix metalloproteinase 3 expression. ${ }^{23}$ We showed the up-regulated metalloproteinase mechanism for ADAMTS9 expression at a higher concentration of $\mathrm{H}_{2} \mathrm{O}_{2}$ in this study.

In the normal physiological conditions, the low concentrations of ROS caused by respiratory function are detoxified by antioxidant substances that are present in the chondrocytes. ${ }^{24}$ These are antioxidant enzymes such as superoxide dismutase. Antioxidant mechanisms may not be sufficient under some pathological conditions like inflammation and may result in apoptosis. ${ }^{25}$

During the last decade, increasing number of studies suggest that intracellular ROS modulates many intracellular signaling pathways. Therefore, ROS has an important role in the inflammation process. RA is one of the systemic diseases, which goes with acute inflammatory episodes. It is known as a connective tissue disorder and 
an autoimmune disease but it is not generally classified as an OS related disease. Reactive oxygen species are important for the management of cell redox status and necessary for normal cell function, such as apoptosis, chemotaxis, aggregation, and proliferation. RA has been associated with increased ROS production or destroyed antioxidant defense system. ${ }^{26-28}$ In RA, the macrophages and polymorphonuclear leukocytes which are present in the joint fluid are the source of $\mathrm{H}_{2} \mathrm{O}_{2} \cdot{ }^{29} \mathrm{ROS}$ in the joint may play a significant role in inflammatory response and lipid peroxidation. ${ }^{30,31}$ However, ROS formed by phagocytes during respiratory burst seem to have an important physiological function in the immune system. ${ }^{32}$ It was experimentally shown that high formation of ROS may result in increased damage to joint cartilage and activation of osteoclast. ${ }^{33,34}$ Additionally, ROS destroy the structure of synovial fluid and depolymerize hyaluronic acid, which results in viscosity loss in the joint. ${ }^{35}$ Superoxide, $\mathrm{H}_{2} \mathrm{O}_{2}$, peroxyl radicals and hydroxyl radical are the main ROS. The hydroxyl radical is especially a reactive molecule that can be produced from $\mathrm{H}_{2} \mathrm{O}_{2}$ nonenzymaticly. ${ }^{36}$ ROS can also react with other molecules such as proteins, lipids, nucleic acids, and other molecules that alter cell structure and cause cell damage. Vitamin $\mathrm{E}$ prevented articular damage in a RA animal model but it did not change the oxidation status or inflammatory process of the disease. ${ }^{37}$

Chondrocyte apoptosis has been implicated in the pathogenesis of OA. Chondrocyte cell death

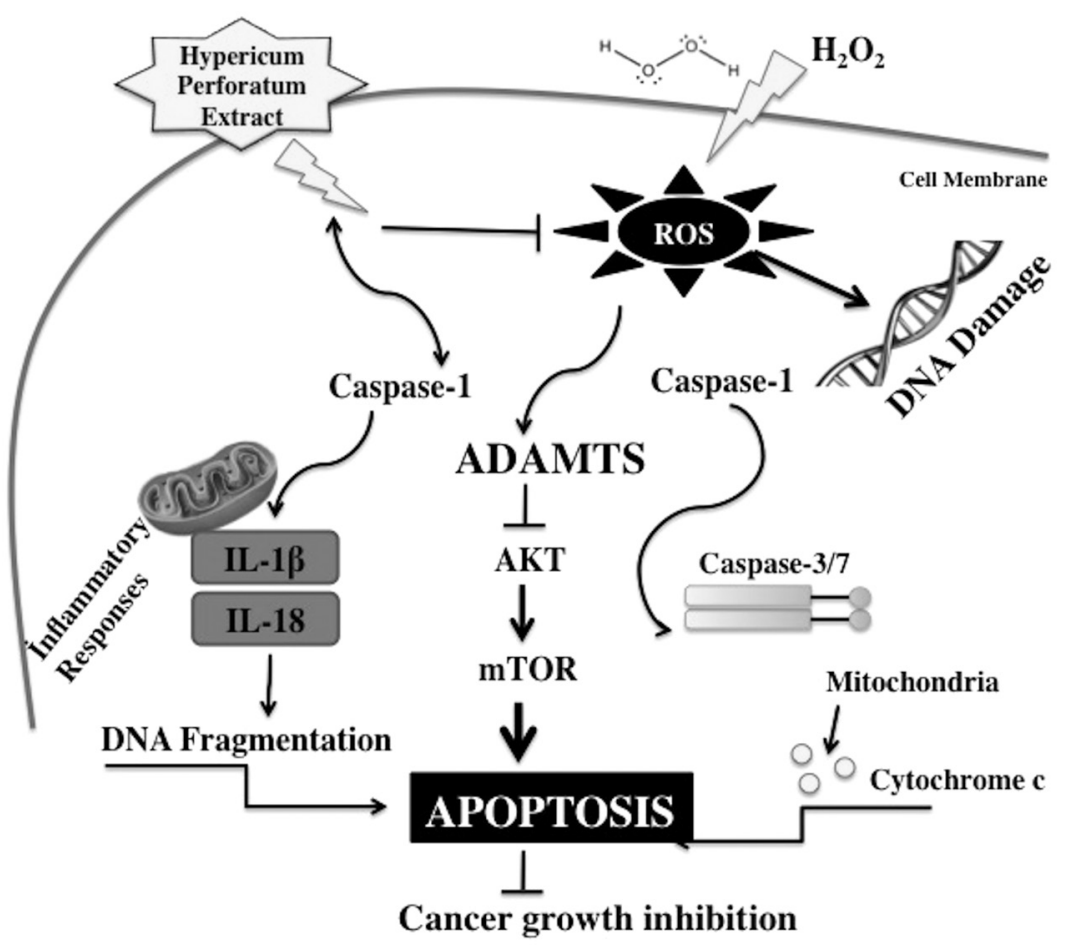

Figure 8. The proposed mechanism and pathway of the effect of both $\mathrm{H}_{2} \mathrm{O}_{2}$ and Hypericum perforatum extract on apoptosis via ROS and caspases. As a tumor supressor gene, ADAMTS gene decreases proliferation through inducing apoptosis. However, the role of interaction of ADAMTS with caspase and ROS remain unclear. ADAMTS9 has been found to be a critical tumor suppressor of gastric cancer progression through suppression of oncogenic AKT/mTOR signaling. ${ }^{51}$ In accordance with our findings, ectopic expression of ADAMTS9 in gastric cancer cell lines (AGS, BGC823) was found to induce apoptosis. The mechanism of the action of ADAMTS is required to be understood more comprehensively. $\mathrm{H}_{2} \mathrm{O}_{2}$ : Hydrogen peroxide; ROS: Reactive oxygen species; DNA: Deoxyribonucleic acid; ADAMTS: A disintegrin-like and metalloproteinase with thrombospondin motifs; IL: Interleukin; AKT: Protein kinase B (PKB); mTOR: Mammalian target of rapamycin. 
can contribute to cartilage degeneration in OA. Therefore, the ability of HPL for the protection of chondrocytes in vitro has been investigated in the present study. As mentioned above, apoptosis and necrosis are two markers of cell death. Apoptosis, also called as programmed cell death, may occur after several pathological conditions and is associated with tissue remodeling, and removal of damaged cells under physiological conditions. Accumulating data suggest that apoptosis of chondrocyte may have a role in the pathophysiology of OA, which is related with degradation of articular cartilage. ${ }^{38}$ The importance of apoptosis induced by $\mathrm{H}_{2} \mathrm{O}_{2}$ is unclear. It is known that $\mathrm{H}_{2} \mathrm{O}_{2}$ inhibits production of proteoglycan, which may result in chondrocyte apoptosis. On the other hand, evidence is insufficient to conclude that $\mathrm{H}_{2} \mathrm{O}_{2}$ effect on cartilage degradation is caused by an increase in apoptosis. More importantly, $\mathrm{H}_{2} \mathrm{O}_{2}$ has been reported to inhibit metabolic pathways, which are enrolled in the chondrocyte signal transduction. Recent literature from other cell lines reports the role of mitochondrial permeability and cytochrome $\mathrm{C}$ release in the apoptosis caused by $\mathrm{H}_{2} \mathrm{O}_{2} \cdot{ }^{39,40}$ Apoptosis is characterized with cell shrinkage, DNA fragmentation, and apoptotic body formation. ${ }^{41}$ The caspases are accepted as important mediators of the apoptotic process and they trigger a cascade of proteolytic reactions (Figure 8). Caspase- 3 is the most commonly studied member of this protein family, and it has a key role in apoptosis, which is responsible for the proteolytic degradation of many proteins. ${ }^{42,43}$

Although the chemical and pharmaceutical properties of HPL extracts are well documented, very little is known about their molecular mode of action. The herbal remedy HPL is a commonly used alternative for the management of depression. Additionally, it inhibits the tumor cell growth by increasing apoptosis. ${ }^{44}$ Proteins regulated by endoplasmic reticulum stress prevent apoptosis of tumor cells. ${ }^{45}$ Endoplasmic reticulum stressregulated proteins might therefore reduce the cell protective effects of some chaperones and result in increased tumor cell apoptosis. Several other studies have shown that some herbal medications have a protective effect on chondrocyte cell death caused by oxidative stress. In this study, it was evaluated if the medicinal plant HPL possesses a protective effect against $\mathrm{H}_{2} \mathrm{O}_{2}$-induced apoptotic cell death in a chondrocyte cell line. Liquid chromatography-mass spectrometry analysis of HPL extract showed that it contains over two dozens of constituents, among which hyperforin, hypericin, pseudohypericin, quercetin, chlorgenic acid, rutin, hyperoside, amentoflavone, etc. are the major active components. ${ }^{46}$ The content of flavonoids is the richest. HPL has antiinflammatory effects due to the inhibition of inducible nitric oxide synthase and nuclear factor- $\kappa \mathrm{B} .{ }^{47}$

In the in vitro studies, HPL extracts with rich flavonoids (FEHP) showed strong antioxidant activity and radical scavenging characteristics. It behaved like a hydrogen-donating substance in the diphenylpicrylhydrazyl assay and an electron-donating substance in the iron III to II reducing assay. It inhibited the peroxidations of lipid membranes and linoleic acid. FEHP also seems to be an effective radical scavenger for superoxide anion. FEHP decreased degradation of deoxyribose mainly due to the chelating iron ions but not scavenging hydroxyl radicals directly. ${ }^{48}$

To the best of our knowledge, this study investigated the effects of $\mathrm{H}_{2} \mathrm{O}_{2}$ in terms of DNA damage, cell viability, apoptosis, and ADAMTS genes in OUMS-27 cells for the first time. A concentration of $0.7 \mathrm{mM}$ of $\mathrm{H}_{2} \mathrm{O}_{2}$, which was revealed as the most efficient dose based on previous applications, was applied to cells. Therefore, concentration effects were not investigated.

Reactive oxygen species formation was detected in chondrocytes after one hour of application of over $0.1 \mathrm{mM} \mathrm{H}_{2} \mathrm{O}_{2} \cdot{ }^{49}$ Lysosomal swelling was detected after one hour of application of $0.1 \mathrm{mM}$ $\mathrm{H}_{2} \mathrm{O}_{2}$ and over, possibly revealing lysosomal membrane instability. Moreover, indications of lysosomal rupture, including release of lysosomal enzymes, were apparent one hour after the addition of $10 \mathrm{mM}$ of $\mathrm{H}_{2} \mathrm{O}_{2}$. The addition of $\mathrm{H}_{2} \mathrm{O}_{2}$ to chondrocytes may induce ROS formation and lysosomal dysfunction, revealed by swelling and rupture, prior to dysfunction of the mitochondrial membrane potential. ${ }^{49}$ Jiang et al. ${ }^{50}$ demonstrated that glucosamine protects nucleus pulposus cells (NPC) and induces autophagy via the mammalian target of rapamycin-dependent pathway. They also showed that glucosamine attenuated the decrease of aggrecan and prevented the apoptosis 
of the NPC induced by IL-1 $\beta$. Similarly, in our setup, we revealed that HPL extract may have effects on DNA damage, apoptosis and aggrecan degradation. Therefore, we can suggest that $\mathrm{H}_{2} \mathrm{O}_{2}$ may trigger oxidative damage and ADAMTSinduced apoptosis in chondrocytes (Figure 8). ${ }^{51}$

Our findings demonstrated that the applied concentration of $\mathrm{H}_{2} \mathrm{O}_{2}$ caused cellular damage in OUMS-27 cells in two hours. Additionally, HPL was observed to protect OUMS-27 against oxidative damage, inhibit the damage of ECM by decreasing ADAMTS5 level, and protect cartilage tissue from the secondary damage upon abnormal and pathological cell death at a dose of $400 \mu \mathrm{g} / \mathrm{ml}$.

In conclusion, the present study provides novel information into the complex effects of HPL on gene expression, and therefore, protein levels of Caspase-1, ADAMTS5, and ADAMTS9. The observed down-regulation of ADAMTS5 genes indicates that HPL may decrease aggrecan degradation and therefore lessen proteoglycan cleavage. A further study is being undertaken to evaluate its antioxidant action in vivo.

\section{Declaration of conflicting interests}

The authors declared no conflicts of interest with respect to the authorship and/or publication of this article.

\section{Funding}

The authors received no financial support for the research and/or authorship of this article.

\section{REFERENCES}

1. Hadjigogos K. The role of free radicals in the pathogenesis of rheumatoid arthritis. Panminerva Med 2003;45:7-13.

2. Muller WE, Singer A, Wonnemann M, Hafner U, Rolli M, Schafer C. Hyperforin represents the neurotransmitter reuptake inhibiting constituent of hypericum extract. Pharmacopsychiatry 1998;31 Suppl 1:16-21.

3. Masuda T, Inaba Y, Maekawa T, Takeda Y, Yamaguchi $\mathrm{H}$, Nakamoto $\mathrm{K}$, et al. Simple detection method of powerful antiradical compounds in the raw extract of plants and its application for the identification of antiradical plant constituents. J Agric Food Chem 2003;51:1831-8.

4. Conforti F, Statti GA, Tundis R, Menichini F, Houghton P. Antioxidant activity of methanolic extract of
Hypericum triquetrifolium Turra aerial part. Fitoterapia 2002;73:479-83.

5. Hu ZP, Yang XX, Chan SY, Xu AL, Duan W, Zhu $\mathrm{YZ}$, et al. St. John's wort attenuates irinotecaninduced diarrhea via down-regulation of intestinal pro-inflammatory cytokines and inhibition of intestinal epithelial apoptosis. Toxicol Appl Pharmacol 2006;216:225-37.

6. Raso GM, Pacilio M, Di Carlo G, Esposito E, Pinto L, Meli R. In-vivo and in-vitro anti-inflammatory effect of Echinacea purpurea and Hypericum perforatum. J Pharm Pharmacol 2002;54:1379-83.

7. Zou YP, Lu YH, Wei DZ. Protective effects of a flavonoid-rich extract of Hypericum perforatum L. against hydrogen peroxide-induced apoptosis in PC12 cells. Phytother Res 2010;24 Suppl 1:S6-S10.

8. Singh NP, McCoy MT, Tice RR, Schneider EL. A simple technique for quantitation of low levels of DNA damage in individual cells. Exp Cell Res 1988;175:184-91.

9. Lampidis TJ, Kurtoglu M, Maher JC, Liu H, Krishan A, Sheft V, et al. Efficacy of 2-halogen substituted D-glucose analogs in blocking glycolysis and killing "hypoxic tumor cells". Cancer Chemother Pharmacol 2006;58:725-34.

10. Asada S, Fukuda K, Nishisaka F, Matsukawa M, Hamanisi C. Hydrogen peroxide induces apoptosis of chondrocytes; involvement of calcium ion and extracellular signal-regulated protein kinase. Inflamm Res 2001;50:19-23.

11. Asada S, Fukuda K, Oh M, Hamanishi C, Tanaka $\mathrm{S}$. Effect of hydrogen peroxide on the metabolism of articular chondrocytes. Inflamm Res 1999;48:399-403.

12. Chen K, Thomas SR, Keaney JF, Jr. Beyond LDL oxidation: ROS in vascular signal transduction. Free Radic Biol Med 2003;35:117-32.

13. Droge $\mathrm{W}$. Free radicals in the physiological control of cell function. Physiol Rev 2002;82:47-95.

14. Uesugi M, Hayashi T, Jasin HE. Covalent cross-linking of immune complexes by oxygen radicals and nitrite. $\mathrm{J}$ Immunol 1998;161:1422-7.

15. Liang HJ, Tsai CL, Lu FJ. Oxidative stress induced by humic acid solvent extraction fraction in cultured rabbit articular chondrocytes. J Toxicol Environ Health A 1998;54:477-89.

16. Hawkins CL, Davies MJ. Oxidative damage to collagen and related substrates by metal ion/hydrogen peroxide systems: random attack or site-specific damage? Biochim Biophys Acta 1997;1360:84-96.

17. Schalkwijk J, van den Berg WB, van de Putte LB, Joosten LA. An experimental model for hydrogen peroxide-induced tissue damage. Effects of a single inflammatory mediator on (peri)articular tissues. Arthritis Rheum 1986;29:532-8.

18. Hampton MB, Orrenius S. Dual regulation of caspase activity by hydrogen peroxide: implications for apoptosis. FEBS Lett 1997;414:552-6. 
19. Kidd VJ. Proteolytic activities that mediate apoptosis. Annu Rev Physiol 1998;60:533-73.

20. Moulton PJ, Goldring MB, Hancock JT. NADPH oxidase of chondrocytes contains an isoform of the gp91phox subunit. Biochem J 1998;329 ( Pt 3):449-51.

21. Moulton PJ, Hiran TS, Goldring MB, Hancock JT. Detection of protein and mRNA of various components of the NADPH oxidase complex in an immortalized human chondrocyte line. Br J Rheumatol 1997;36:522-9.

22. Lo MY, Kim HT. Chondrocyte apoptosis induced by hydrogen peroxide requires caspase activation but not mitochondrial pore transition. J Orthop Res 2004;22:1120-5.

23. Martin G, Andriamanalijaona R, Mathy-Hartert M, Henrotin Y, Pujol JP. Comparative effects of IL-1beta and hydrogen peroxide (H2O2) on catabolic and anabolic gene expression in juvenile bovine chondrocytes. Osteoarthritis Cartilage 2005;13:915-24.

24. Baker MS, Feigan J, Lowther DA. Chondrocyte antioxidant defences: the roles of catalase and glutathione peroxidase in protection against $\mathrm{H} 2 \mathrm{O} 2$ dependent inhibition of proteoglycan biosynthesis. J Rheumatol 1988;15:670-7.

25. Toussaint O, Medrano EE, von Zglinicki T. Cellular and molecular mechanisms of stress-induced premature senescence (SIPS) of human diploid fibroblasts and melanocytes. Exp Gerontol 2000;35:927-45.

26. Ozturk HS, Cimen MY, Cimen OB, Kacmaz M, Durak I. Oxidant/antioxidant status of plasma samples from patients with rheumatoid arthritis. Rheumatol Int 1999;19:35-7.

27. Aaseth J, Haugen M, Forre O. Rheumatoid arthritis and metal compounds--perspectives on the role of oxygen radical detoxification. Analyst 1998;123:3-6.

28. Winrow VR, Winyard PG, Morris CJ, Blake DR. Free radicals in inflammation: second messengers and mediators of tissue destruction. $\mathrm{Br}$ Med Bull 1993;49:506-22.

29. Lowther DA, Sandy JD, Santer VB, Brown HL. Antigen-induced arthritis. Decreased proteoglycan content and inhibition of proteoglycan synthesis in articular cartilage. Arthritis Rheum 1978;21:675-80.

30. Mantle D, Falkous G, Walker D. Quantification of protease activities in synovial fluid from rheumatoid and osteoarthritis cases: comparison with antioxidant and free radical damage markers. Clin Chim Acta 1999;284:45-58.

31. Dularay B, Elson CJ, Dieppe PA. Enhanced oxidative response of polymorphonuclear leukocytes from synovial fluids of patients with rheumatoid arthritis. Autoimmunity 1988;1:159-69.

32. Jones DP. Disruption of mitochondrial redox circuitry in oxidative stress. Chem Biol Interact 2006;163:38-53.

33. Goldring SR. Pathogenesis of bone erosions in rheumatoid arthritis. Curr Opin Rheumatol 2002;14:406-10.

34. Miossec P. An update on the cytokine network in rheumatoid arthritis. Curr Opin Rheumatol 2004;16:218-22.

35. McCord JM. Free radicals and inflammation: protection of synovial fluid by superoxide dismutase. Science 1974;185:529-31.

36. Gutteridge JM, Rowley DA, Halliwell B. Superoxidedependent formation of hydroxyl radicals in the presence of iron salts. Detection of 'free' iron in biological systems by using bleomycin-dependent degradation of DNA. Biochem J 1981;199:263-5.

37. De Bandt M, Grossin M, Driss F, Pincemail J, BabinChevaye C, Pasquiler C. Vitamin E uncouples joint destruction and clinical inflammation in a transgenic mouse model of rheumatoid arthritis. Arthritis Rheum 2002;46:522-32.

38. Hashimoto S, Ochs RL, Komiya S, Lotz M. Linkage of chondrocyte apoptosis and cartilage degradation in human osteoarthritis. Arthritis Rheum 1998;41:1632-8.

39. Dumont A, Hehner SP, Hofmann TG, Ueffing M, Droge W, Schmitz ML. Hydrogen peroxide-induced apoptosis is CD95-independent, requires the release of mitochondria-derived reactive oxygen species and the activation of NF-kappaB. Oncogene 1999;18:747-57.

40. von Harsdorf R, Li PF, Dietz R. Signaling pathways in reactive oxygen species-induced cardiomyocyte apoptosis. Circulation 1999;99:2934-41.

41. Chandra J, Samali A, Orrenius S. Triggering and modulation of apoptosis by oxidative stress. Free Radic Biol Med 2000;29:323-33.

42. Cohen GM. Caspases: the executioners of apoptosis. Biochem J 1997;326 (Pt 1):1-16.

43. Eastman A, Barry MA. The origins of DNA breaks: a consequence of DNA damage, DNA repair, or apoptosis? Cancer Invest 1992;10:229-40.

44.Schempp CM, Kirkin V, Simon-Haarhaus B, Kersten A, Kiss J, Termeer CC, et al. Inhibition of tumour cell growth by hyperforin, a novel anticancer drug from St. John's wort that acts by induction of apoptosis. Oncogene 2002;21:1242-50.

45. Jamora C, Dennert G, Lee AS. Inhibition of tumor progression by suppression of stress protein GRP78/ $\mathrm{BiP}$ induction in fibrosarcoma B/C10ME. Proc Natl Acad Sci U S A 1996;93:7690-4.

46. Huang N, Rizshsky L, Hauck C, Nikolau BJ, Murphy PA, Birt DF. Identification of anti-inflammatory constituents in Hypericum perforatum and Hypericum gentianoides extracts using RAW 264.7 mouse macrophages. Phytochemistry 2011;72:2015-23.

47. Tedeschi E, Menegazzi M, Margotto D, Suzuki H, Forstermann U, Kleinert H. Anti-inflammatory actions of St. John's wort: inhibition of human inducible nitric-oxide synthase expression by down-regulating signal transducer and activator of transcription-1alpha 
(STAT-1alpha) activation. J Pharmacol Exp Ther 2003;307:254-61.

48. Zou Y, Lu Y, Wei D. Antioxidant activity of a flavonoidrich extract of Hypericum perforatum L. in vitro. J Agric Food Chem 2004;52:5032-9.

49. Takahashi T, Kitaoka K, Ogawa Y, Kobayashi T, Seguchi H, Tani T, et al. Lysosomal dysfunction on hydrogen peroxide-induced apoptosis of osteoarthritic chondrocytes. Int J Mol Med 2004;14:197-200.
50. Jiang L, Jin Y, Wang H, Jiang Y, Dong J. Glucosamine protects nucleus pulposus cells and induced autophagy via the mTOR-dependent pathway. J Orthop Res. 2014 Aug 2. [Epub ahead of print]

51. Du W, Wang S, Zhou Q, Li X, Chu J, Chang Z, et al. ADAMTS9 is a functional tumor suppressor through inhibiting AKT/mTOR pathway and associated with poor survival in gastric cancer. Oncogene 2013;32:339-28. 